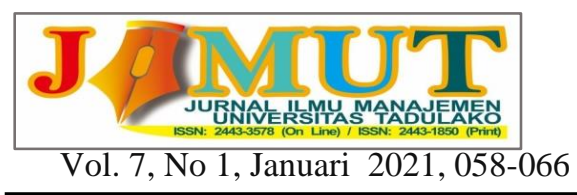

\title{
PENGARUH KEPUASAN DAN KEPERCAYAAN TERHADAP LOYALITAS NASABAH BANK MANDIRI SYARIAH CABANG PALU
}

\author{
Inggrit Puspita Sari, Zakiyah Zahara \\ Program Studi S1 Jurusan Manajemen Fakultas Ekonomi dan Bisnis, Universitas Tadulako \\ Email: inggritpuspitas@gmail.com; Zakiyah66.zm@gmail.com
}

\begin{abstract}
This study aims to determine the effect of satisfaction and trust on customer loyalty at the Mandiri branch of the Syariah Bank in Palu. This type of research is causal research. The independent variable is satisfaction $\left(X_{1}\right)$ and trust $\left(X_{2}\right)$, while the dependent variable is customer loyalty $(Y)$. Data collection methods used were interview observation and questionnaires. The sampling technique used purposive sampling with a total sample of 60 respondents. Data analysis method uses multiple linear regression with the help of software 22 fofr windows. The results of this study indicate that the satisfaction and trust variables simultaneously have a significant effect on customer loyalty. The trust that is generated by the customer will lead to a commitment or promise to be loyal customers in the Mandiri Bank Syariah branch of the Palu City.
\end{abstract}

Keywords: Satisfaction, Trust, Customer Loyalty, Bank Mandiri Syariah.

\begin{abstract}
Abstrak
Penelitian ini bertujuan untuk mengetahui pengaruh kepuasan dan kepercayaan terhadap loyalitas nasabah di Bank Mandiri Syariah Cabang Palu. Jenis penelitian ini merupakan penelitian kausal. Variabel independen adalah kepuasan $\left(\mathrm{X}_{1}\right)$ dan kepercayaan $\left(\mathrm{X}_{2}\right)$, sedangkan variabel dependen adalah loyalitas nasabah (Y). Metode pengumpulan data yang digunakan adalah observasi, wawancara dan kuesioner. Teknik penarikan sampel menggunakan purposive sampling dengan jumlah sampel sebanyak 60 responden. Metode analisis data menggunakan regresi linear berganda dengan bantuan software SPSS 22 for windows. Hasil penelitian ini membuktikan bahwa variabel kepuasan dan kepercayaan sebagai bersama-sama berdampak signifikan terhadap loyalitas nasabah. Kepercayaan yang ditimbulkan oleh nasabah akan memunculkan sikap komit atau berjanji untuk setia menjadi nasabah di Bank Mandiri Syariah Cabang Palu.
\end{abstract}

Kata kunci: Kepuasan, Kepercayaan, Loyalitas Nasabah, Bank Mandiri Syariah.

\section{PENDAHULUAN}

Bank Syariah merupakan Lembaga Keuangan Bank. Bank syariah dapat berbentuk Bank Umum Syariah (BUS) maupun Bank Perkreditan Rakyat Syariah (BPRS). Menurut Undang-Undang Nomor 21 adalah bank yang menjalankan kegiatan usahanya berdasarkan prinsip syariah. Bank umum syariah (BUS) adalah bank syariah yang kegiatannya memberikan jasa dalam lalu lintas pembayaran. (Salman, 2012:8).

Perkembangan Ekonomi Islam akhir-akhir ini begitu pesat. Perkembangan lembaga keuangan syariah di Indonesia tahun 2008 tentang perbankan syariah Indonesia, dijelaskan bahwa bank syariah mengalami peningkatan pesat dari tahun ketahun. Hal ini menunjukkan kinerja perbankan syariah cukup baik sehingga berkontribusi positif bagi pertumbuhan perekonomian di Indonesia. Bukti nyata mengenai kinerja perbankan syariah telah bisa dikatakan sudah cukup baik, dimana saat terjadi keterpurukan perekonomian Indonesia bank konvensional lain sudah terpuruk dan bank syariah masih dapat bertahan dengan cara menunjukkan bukti perkembangannya. (Salman, 2012:8). Salah satu Bank Umum Syariah (BUS) yang memiliki peran penting dalam kelanjutan Perbankan Syariah di Indonesia adalah Bank Syariah Mandiri (BSM). 
Bank Mandiri Syariah Cabang Kota Palu ialah lembaga perbankan di Indonesia. Bank ini berdiri 1995 dengan nama Bank Industri Nasional, bank ini beberapa kali berganti nama dan terakhir kali berganti menjadi Bank Syariah Mandiri pada tahun 1999 setelah sebelumnya bernama Bank Susila Bakti yang memiliki Yayasan tenaga kerja Bank Dagang Negara dan Pt Mahkota Prestasi.

Tjiptono, Fandi (2010: 25) Mendefinisikan kepuasan konsumen ialah, sebagai sejauh mana kinerja barang atau jasa yang memenuhi harapan nasabah. Bila kinerja produk itu lebih rendah daripada harapan konsumen, maka konsumen tersebut merasa puas. Menurut Firdayanti (2012) Kepercayaan pelanggan sangat penting bagi sebuah perusahaan, karena perusahaan tidak dapat membangun hubungan yang kenyataanya konsumen tanpa adanya harapan. Kepercayaan seseorang untuk berperilaku tertentu karena dia meyakini bahwa mitranya dalam melakukan transaksi akan memberikan apa yang dia harapkan.

Tabel 1. Produk dan Layanan Bank Mandiri Syariah Tahun 2018

\begin{tabular}{ccc}
\hline & $\begin{array}{c}\text { Produk dan Layanan Bank } \\
\text { Mandiri Syariah }\end{array}$ & Nasabah Tahun \\
\hline 1 & Tabungan BMS & 579 \\
2 & Tabungan Simpatik & 301 \\
3 & Tabungan Marbur & 287 \\
4 & Tabungan Saham & 201 \\
5 & Tabungan Investa (Berjangka) & 345 \\
Jumlah nasabah & & 1.713 \\
\hline
\end{tabular}

Sumber : Data, diolah.

Berdasarkan Tabel 1 data produk dan layanan Bank Mandiri Syariah ada lima jenis tabungan dan jumah nasabahnya di tahun 2018 adalah 1.713 nasabah. Dari tabel ini menunjukkan bahwa tabungan yang sering dan terbanyak digunakan di Bank Mandiri Syariah adalah tabungan BMS Tabungan BMS merupakan tabungan harian yang menggunakan mata uang rupiah (baik setoran maupun penarikan). Transaksi tersebut dilakukan secara langsung melalui teller BMS atau lebih mudah dan fleksibel biasa melalui ATM.

\section{KAJIAN LITERATUR DAN PENGEMBANGAN HIPOTESIS Bank}

Menurut Kasmir (2012:14) Bank membentuk industri yang beralih dalam aspek keuangan, artinya aktivitas perbankan selalu berkaitan dalam bidang keuangan sehingga berbicara mengenai bank tidak terlepas dari masalah keuangan. Bisnis perbankan memperluas tiga kegiatan utama, yaitu menghimpun dana, menyalurkan dana, dan menyediakan jasa bank lainnya. Bank juga merupakan bentuk norma keuangan yang melancarkan beragam macam jasa, sebagaimana melepaskan pinjaman, mengedar mata uang, pengawasan terhadap mata uang, bertindak demi tempat penabung benda-benda berharga, membayar bisnis perusahaan-perusahaan, dan lain-lain.

\section{Perbankan Syariah}

Menurut Kasmir (2012: 14) Undang-undang No.10 tahun 1998 Bank Syariah adalah Bank yang melaksanakan kegiatan bisnisnya berdasarkan prinsip syariah islam. Prinsip Syariah menurut Pasal 1 ayat 13 Undang-undang No.10 tahun 1998 tentang perbankan adalah adat kesepakatan berlandaskan hukum islam jarak bank atas bagian lain demi penyimpanan dana maupun pembiayaan aktivitas bisnis, 


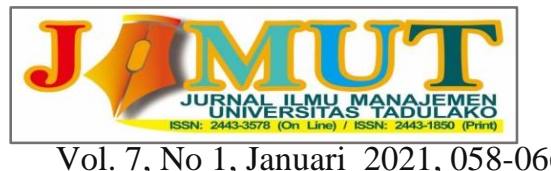

Vol. 7, No 1, Januari 2021, 058-066

atau kegiatan lainnya yang dinyatakan sesuai dengan syariah antara lain pembiayaan berdasarkan bagi hasil (mudharabah), pembiayaan berdasarkan prinsip penyertaan modal (musyarakah), prinsip jual beli barang dengan keuntungan (murabahah), atau pembiayaan barang modal berdasarkan sewa murni tanpa pilihan (ijarah), atau dengan adanya pilihan pemindahan kepemilikan atas barang yang disewa dari pihak bank oleh pihak lain. Bank Syariah ialah Perbankan yang segala seluruh yang melibat bank syariah dan unit usaha syariah, mencakup kelembagaan, kegiatan usaha, serta cara dan proses dalam melakukan aktivitas bisnisnya. Nama bank syariah sebenarnya hanya digunakan di Indonesia saja, bank syariah pada internasional disebut sebagai bank islam.

\section{Kepuasan Pelanggan}

Menurut Sunyoto (2013: 35), kepuasan pelanggan ialah derajat perasaan seseorang setelah membandingkan (kinerja atau hasil) yang dirasakan dibandingkan dengan tujuannya. Pelanggan dapat mengalami salah satu dari tiga tingkat kepuasan yaitu kalau kinerja dibawah harapan, konsumen merasa kecewa tetapi jika kinerja sesuai dengan harapan pelanggan akan merasa puas dan apabila kinerja bisa melebihi harapan maka pelanggan akan merasakan sangat puas senang atau gembira.

Menurut Hasan Ali (2014: 90) kepuasan atau ketidakpuasan melambangkan respons konsumen terhadap evaluasi ketidakpuasan yang dipersepsikan antara harapan sebelum pembelian dari kinerja aktual produk/jasa yang dirasakan setelah pemakaiannya. Menurut Lupiyoadi (2011:182) dimensi kepuasan konsumen terdapat empat elemen yaitu 1). Kualitas produk, konsumen merasa puas apabila penilaian mereka membuktikan bahwa barang yang mereka gunakan berkualitas.2). Faktor kemudahan, konsumen lebih merasakan kepuasan bila relatif gampang, aman dan praktis dalam memiliki barang atau pelayanan. 3). Kualitas pelayanan, konsumen lebih merasa puas bila mereka memiliki pelayanan terbaik atau sesuai dengan harapan. 4). Faktor emosional, konsumen lebih merasa angkuh dan mendaptkan kayakinan bahwa orang lain kagum bila konsumen menggunakan produk merek tertentu.

\section{Kepercayaan Pelanggan}

Menurut Firdayanti (2012) Kepercayaan pelanggan sangat penting bagi sebuah perusahaan, karena perusahaan tidak dapat membangun hubungan yang sesungguhnya dengan konsumen tanpa adanya kepercyaan. Kepercayaan seseorang demi berperilaku khusus karena meyakini bahwa mitranya dalam melakukan transaksi memberikan apa yang dia harapkan.

Menurut Firdayanti (2012) terdapat empat dimensi kepercayaan seseorang antara lain yaitu kemampuan, kebaikan hati, integritas, dan kehormatan. Berikut keempat aspek dapat diketahui 1). Kemampuan (ability, Kemampuan ialah kepercayaan seseorang atau kemampuan yang dimiliki penjual demi membantu pelanggan dalam menjalankan sesuatu sesuai dengan yang dibutuhkan pelanggan tersebut.2). Kebaikan hati (benevolence), Kebaikan hati adalah seberapa banyak seseorang membenarkan pada penjual demi berperilaku baik kepada pelanggan. 3). Integritas (integrity), Integritas ialah seberapa besar keyakinan seseorang terhadap kejujuran pejual demi melindungi dan memadati kesepakatan yang telah dibuat kepada pelanngan. 4). Kehormatan (honesty, Kehormatan ialah seberapa besar arti sebuah kehormatan bagi perusahaan dalam melakukan bisnis.

\section{Loyalitas Pelanggan}

Menurut Tjiptono dan Fandi (2010:312) Loyalitas adalah suatu komitmen yang menggenggam teguh demi membeli kembali atau berlangganan produk pilihan atau jasa di masa depan maupun akibat situasional dan cara pemasaran memounyai kekuatan demi membangkit konsumen beralih ke produk lain. Loyalitas konsumen (customer loyalty) adalah komitmen konsumen terhadap merek pemasok yang tercermin dari sikap (attitude) yang sangat positif dan wujud perilaku (behavior) pembelian ulang yang dilakukan oleh konsumen tersebut secara konsisten. Berarti konteks merek, misalnya loyalitas membayangkan janji psikologis terhadap merek tertentu, olehnya karakter pembelian ulang semata-mata menyangkut pembelian merek yang sama secara berulangkali (bisa dikarenakan memang 
karena satu-satunya merek yang tersedia, merek yang termurah. Adapun indikator-indikator untuk mengukur variabel tersebut adalah:

1. Akan tetap menjadi pelanggan.

2. Membeli produk secara berulang.

3. Merekomendasikan produk terhadap orang lain.

4. Menawarkan secara umum.

\section{METODE PENELITIAN}

Jenis penelitian ini, yaitu penelitian deskriptif kausal, karena tujuan utamanya adalah memperoleh data informasi tentang pengaruh kepuasan dan kepercayaan terhadap loyalitas nasabah di Bank Mandiri Syariah Cabang Kota Palu. Pada penelitian ini, peneliti secara langsung melakukan riset pada objek penelitian, dengan maksud mengetahui pengaruh kepuasan dan kepercayaan terhadap loyalitas di Bank Mandiri Syariah Cabang Palu artinya peneliti akan mencoba pengaruh variabel independen terhadap variabel dependen dengan maksud untuk menguji hipotesis melalui penelitian statistik. Subjek penelitian ini ialah pelanggan yang mengisi kuesioner pada Bank Mandiri Syariah. Populasi penelitian ini ialah nasabah yang menggunakan tabungan BMS pada bank mandiri syariah cabang palu, dengan syarat bersedia mengisi kuisioner yang diberikan nasabah Bank Mandiri Syariah, berusia di atas 17 tahun. Karena tidak adanya data pendukung yang tersedia dalam penelitian ini, maka jumlah populasinya tidak diketahui. Teknik penarikan sampel yang digunakan penelitian ini ialah purposive sampling. Sugiyono (2016: 85) berpendapat bahwa purposive sampling ialah teknik pemastian sampel atas alasan tertentu. Dikarenakan total populasinya bukan diketahui sebagai menentukan besarnya sampel digunakan rumus unknown populations sebagai berikut:

$$
\frac{n=Z^{2}}{4 \mu^{2}}
$$

Keterangan :

$\mathrm{n}=$ bentuk sampel

$\mathrm{Z}=$ keyakinan sampel dibutuhkan

Dalam penelitian (pada $\alpha=5 \%$ atau derajat keyakinan ditentukan $95 \%$

maka $\mathrm{Z}=1,60$ )

$\mu=$ margin of error, tingkat kesalahan yang dapat ditolerir ditentukan $10 \%$

Dengan menggunakan rumus di atas, maka diperoleh perhitungan sebagai berikut:

$$
\begin{gathered}
\mathrm{n}=\frac{\mathrm{Z}^{2}}{4 \mu^{2}} \\
\mathrm{n}=\frac{1.60^{2}}{4(0,1)^{2}} \\
\mathrm{n}=60,4=60 \text { responden. }
\end{gathered}
$$

\section{Metode Pengumpulan Data}

Dalam melakukan penelitian ini, peneliti menggunakan beberapa tenik pengumpulan data, yaitu:

\section{Observasi}

Sugiyono (2014: 145) Observasi merupakan proses yang tersusun dari berbagai proses bilogis dan psikologis. Dua diantara yang terutama ialah proses pengamatan dan ingatan. Lokasi observasi penelitian disini adalah di Bank Mandiri Syariah Cabang Palu.

2. Wawancara 
Sugiyono (2014: 137) Wawancara digunakan sebagai pengumpulan data apabila peneliti ingin melakukan studi pendahuluan untuk menemukan permasalahan yang harus diteliti, dan juga apabila peneliti ingin mengetahui hal-hal dari responden yang lebih mendalam dan jumlah responden sedikit kecil. Wawancara penelitian ini dilakukan dengan tanya jawab secara langsung kepada nasabah yang telah menggunakan produk Bank Mandiri Syariah.

\section{Kuisioner}

Sugiyono (2014:142) Kuisioner merupakan teknik pengumpulan data yang dilakukan dengan memberikan pertanyaan atau pernyataan tertulis kepada responden untuk dijawabnya. Penulis mengedarkan kuesioner yang terdiri dari sejumlah daftar pertanyaan yang terstruktur kepada nasabah yang menggunakan produk di Bank Mandiri Syariah.

\section{Definisi Operasional Variabel}

Variabel ini didefinisikan secara operasional agar lebih mudah dicari hubungannya secara satu variabel dengan lainnya dan pengukurannya. Sugiyono (2016:38) menjelaskan variabel penelitian adalah segala sesuatu yang berbentuk apa saja yang ditetapkan oleh peneliti untuk dipelajari sehingga diperoleh informasi tentang hal tersebut, kemudian ditarik kesimpulannya. Penelitian ini terdiri dari dua jenis variabel yaitu variabel bebas/independen $(\mathrm{X})$ dan variabel terikat/dependen (Y). Variabel penelitian mencerminkan karakteristik populasi yang ingin di telah. Dalam penelitian ini, yang merupakan variabel independen (variabel bebas) adalah Kepuasan $\left(\mathrm{X}_{1}\right)$ dan Kepercayaan $\left(\mathrm{X}_{2}\right)$, serta variabel dependen (variabel terikat) yaitu Loyalitas nasabah (Y). Adapun rincian indikator dari masing-masing variabel tersebut adalah sebagai berikut:

1. Variabel Independen (Kepuasan, X1)

a. Kualitas produk

Maksud dari variabel kualitas produk yaitu dimana pelanggan akan merasa puas dengan hasil evaluasi mereka menunjukkan bahwa produk yang mereka gunakan berkualitas.

b. Faktor Kemudahan

Maksud dari variabel faktor kemudahan adalah pelanggan akan semakin merasakan kepuasan apabila relative mudah, nyaman dan efisien dalam mendapatkan produk atau pelayanan.

c. Kualitas pelayanan

Maksud dari variabel kualitas pelayanan adalah pelanggan akan merasa puas karna mereka mendapatkan pelayanan yang baik atau sesuai dengan harapanya.

d. Faktor emosional

Maksud dari variabel faktor emosinal adalah pelanggan akan merasakan

bangga dan mendaptkan keyakinan bahwa orang lain kagum bila konsumen menggunakan produk mereka tertentu.

2. Variabel Independen (Kepercayaan, X2)

a. Kemampuan (ability)

Maksud dari dimensi kemampuan adalah seberapa besar keberhasilan penjua latau pelaku bisnis agar menghasilkan hal yang diinginkan oleh konsumen.

b. Kebaikan hati (benevolence)

Maksud dari dimensi kebaikan hati yaitu seberapa besar seseorang percaya kepada penjual dan berperilaku baik kepada pelanggan.

c. Integritas (integrity)

Maksud dari dimensi ini yaitu begitu besar keyakinan seseorang terhadap kujujuran penjual untuk menjaga dan memenuhi kesepakatan yang telah dibuat kepada pelanggan.

d. Kehormatan (honesty) 
Maksud dari dimensi ini adalah seberapa besar arti sebuah kehormatan bagi perusahaan dalam melakukan bisnis.

3. Variabel Dependen (Y)

Dalam penelitian ini, variabel dependen (Y) yaitu loyalitas pelanggan. Maksud dari loyalitas pelanggan adalah pelanggan yang telah puas menggunakan produk dari suatu perusahaan dan akan melakukan pembelian secara terus menerus.

\section{HASIL DAN PEMBAHASAN}

\section{Karakteristik Responden}

Jumlah kuesioner yang dibagi dalam penelitian ini sebanyak 60 kuesioner dengan subjek penelitiannya adalah nasabah pada Bank Mandiri Syariah Cabang Palu dengan syarat usia yang sudah ditentukan dengan usia lebih dari 17 tahun. Kuesioner ini dibagikan langsung kepada responden tanpa ada rentang waktu yang lama antara pengisian dan pengembalian kuesioner sehingga tidak memiliki resiko untuk tidak dikembalikan. Dari 60 kuesioner yang dibagikan, semua memiliki jawaban yang lengkap sehingga layak untuk dianalisis. Di bawah ini akan dipaparkan karakteristik responden menurut jenis kelamin, usia, pekerjaan, pendidikan terakhir, pendapatan perbulan dan kriteria responden.

\section{Hasil Uji Regresi Linear Berganda}

Uji analisis ini untuk memahami pengaruh variabel independen kepuasan dan kepercayaan terhadap variabel dependen loyalitas nasabah pada tabel berikut ini:

Tabel 2. Regresi Linear Berganda

\begin{tabular}{|c|c|c|c|c|}
\hline \multicolumn{5}{|c|}{ Variabel Dependen $(\mathrm{Y})=$ Loyalitas Nasabah } \\
\hline \multirow{2}{*}{$\begin{array}{l}\text { Variabel Independen } \\
\text { (X) } \\
\text { (Constant) }\end{array}$} & \multicolumn{2}{|c|}{$\begin{array}{l}\text { Unstandardized } \\
\text { Coefficient }\end{array}$} & \multirow{3}{*}{$\begin{array}{l}\text { Standardized } \\
\text { Coefficient } \\
\text { Beta }\end{array}$} & \multirow[t]{3}{*}{ Sig.t } \\
\hline & \multirow{3}{*}{$\begin{array}{l}\text { B } \\
0,359\end{array}$} & Std. & & \\
\hline & & Eror & & \\
\hline & & 0,416 & & 0,341 \\
\hline Kepuasan & 0,046 & 0,027 & 0,204 & 0 \\
\hline Kepercayaan & 0,315 & 0,058 & 0,656 & 0,000 \\
\hline Multiple R & 0,825 & Sig. F & & 0,000 \\
\hline R square & 0,680 & & & \\
\hline Adjusted R Square & 0,669 & & & \\
\hline
\end{tabular}

Sumber : Data, diolah.

Berdasarkan hasil uji regresi padaTabel 2 tersebut, diperoleh persamaan regresi sebagai berikut:

$Y=0.359+0.046 X_{1}+0.315 X_{2}$

1. Nilai konstanta sebesar 0,359 , artinya variabel (kepuasan dan kepercayaan) bernilai 0 atau konstan, maka variabel dependen (loyalitas nasabah) nilainya sebesar 0,359.

2. Koefisien regresi dimensi kepuasan $\left(\mathrm{X}_{1}\right)$ sebesar 0,046 , artinya bahwa pengaruh variabel kepuasan loyalitas nasabah pada Bank Mandiri Syariah Cabang Palu adalah bersifat positif dan jika skor variabel kepuasan meningkat maka variabel loyalitas nasabah juga meningkat. 
3. Koefisien regresi dimensi kepercayaan $\left(\mathrm{X}_{2}\right)$ 0,315, artinya bahwa pengaruh variabel kepercayaan atas loyalitas nasabah pada Bank Mandiri Syariah Cabang Palu adalah bersifat positif dan jika skor variabel kepercayaan meningkat maka variabel loyalitas nasabah juga meningkat.

\section{Hasil Uji Hipotesis}

\section{Hasil Pengujian Hipotesis Koefisien Determinasi Ganda (Uji F)}

Jika nilai probabilitas Sig $\mathrm{F} \leq \alpha(0,05)$, maka seluruh variabel bebas yang diamati secara serempak berpengaruh signifikan terhadap variabel tidak bebas (Y). Sebaliknya jika nilai probabilitas Sig $\mathrm{F} \geq \alpha(0,05)$, maka seluruh variabel bebas yang diamati diamati secara serempak atau bersama-sama berpengaruh tidak signifikan atas variabel tidak bebas (Y).

Berdasarkan hasil uji regresi diperoleh nilai Sig F $0,000<\alpha(0,05)$, dengan demikian maka dapat disimpulkan bahwa keempat variabel bebas yang diteliti, secara bersama-sama atau serempak memberikan pengaruh signifikan terhadap variabel loyalitas pelanggan. Demikian hipotesis ini diterima.

\section{Hasil Pengujian Hipotesis Koefisien Determinasi Parsial (Uji t)}

Uji $\mathrm{t}$ adalah untuk mengetahui apakah variabel kepuasan dan kepercayaan secara parsial berpengaruh terhadap Y. Berdasarkan hasil uji t pengujian variabel $\left(\mathrm{X}_{1}-\mathrm{X}_{2}\right)$ terhadap Y dijelaskan sebagai berikut:

1. Hasil Pengujian Hipotesis $\mathrm{X}_{1}$ terhadap $\mathrm{Y}$

Hasil pengujian hipotesis kedua $\left(\mathrm{H}_{2}\right)$ digunakan untuk mengetahui apakah variabel kepuasan $\left(\mathrm{X}_{1}\right)$ secara berpengaruh signifikan terhadap loyalitas nasabah di Bank Mandiri Syariah Cabang Palu. Berdasarkan hasil uji t pada Tabel 5.19 di atas menunjukkan bahwa variabel kepuasan $\left(\mathrm{X}_{1}\right)$ memiliki pengaruh signifikan sebesar 0,004 . Artinya, nilai tersebut $<$ (kurang dari) dari taraf yang diisyaratkan yaitu $\propto=0,05$.Oleh karena itu, dapat disimpulkan bahwa kepuasan berpengaruh signifikan terhadap loyalitas nasabah di Bank Mandiri Syariah Cabang Palu.

2. Hasil Pengujian Hipotesis $X_{2}$ terhadap $Y$

Hasil pengujian hipotesis ketiga $\left(\mathrm{H}_{3}\right)$ digunakan untuk mengetahui apakah variabel kepercayaan $\left(\mathrm{X}_{2}\right)$ berpengaruh signifikan terhadap loyalitas nasabahdi Bank Mandiri Syariah Cabang Palu. Berdasarkan hasil uji t menunjukkan bahwa variabel kepercayaan $\left(\mathrm{X}_{2}\right)$ memiliki pengaruh signifikan sebesar 0,000 . Artinya, nilai tersebut $<$ (kurang dari) dari taraf yang diisyaratkan yaitu $\propto$ $=0,05$. Oleh karena itu, dapat disimpulkan bahwa kepercayaan berpengaruh signifikan terhadap loyalitas nasabah di Bank Mandiri Syariah Cabang Palu.

\section{Pembahasan Hasil Penelitian}

\section{Analisis Secara Simultan}

Dari hasil pengujian serta analisis yang telah dilakukan pada penelitian ini membuktikan bahwa variabel kepuasan dan keprcayaan secara simultan berpengaruh signifikan terhadap loyalitas nasabah di Bank Mandiri Syariah Cabang Palu. Berdasarkan tabel rekapitulasi regresi linear berganda, dapat dilihat pengaruh hasil uji determinasi $R$ Square sebesar 0,680. Nilai tersebut dapat diartikan bahwa kepuasan dan kepercayaan mempunyai konstribusi secara bersama-sama sebesar 68\% terhadap variabel terikat yaitu loyalitas nasabah di Bank Mandiri Syariah Cabang Palu. Sedangkan sisanya $(100 \%-68 \%=32 \%)$.

\section{Analisis Secara Parsial}

1. Variabel Kepuasan $\left(\mathrm{X}_{1}\right)$

Berdasarkan hasil uji regresi, terbukti bahwa variabel kepuasan $\left(X_{1}\right)$ memengaruhi loyalitas nasabah di Bank Mandiri Syariah Cabang Palu. Sedangkan dalam hasil uji t kepuasan menjadi kedua dominan dengan hasil 0,004. Dimana dimensiyang pertama dalam penelitian ini kualitas 


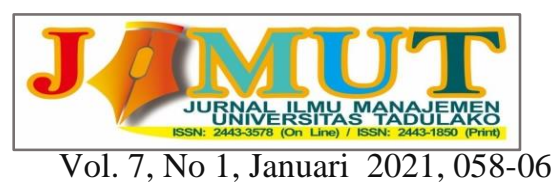

Vol. 7, No 1, Januari 2021, 058-066

produk, dimana produk-produk Bank Mandiri Syariah yang mereka tawarkan bersaing dengan produk bank lain, dan jenis-jenis produknya sesuai dengan kebutuhan nasabah, sehingga memudahkan nasabah dalam membuka rekening di bank tersebut. Dimensi yang kedua dalam penelitian ini faktor kemudahan, dimana karyawan Bank Mandiri Syariah mampu memberikan pemahaman tentang produk-produk yang mereka tawarkan kepada nasabah dan fasilitas Bank Mandiri Syariah card, e-banking memudahkan nasabah bertransaksi kapanpun dimanapun. Dimensi selanjutnya, kualitas layanan, dimana Bank Mandiri Syariah dapat memberikan pelayanan dan antusias dalam menyabut nasabah, dapat membantu nasabah mengalami masalah dalam melakukan transaksi, dan pelayanan yang sama kepada seluruh nasabah tanpa membedakan status sosial nasabah. selanjutnya, faktor emosional dimana Bank Mandiri Syariah dapat mengimplementasikan bisnisnya berdasarkan prinsip Syariat Islam dan dana yang disimpan di Bank Mandiri Syariah aman dan terjamin. Oleh karena itu diharapkan Bank Mandiri Syariah dapat mempertahankan dan meningkatkan yang menjadi tujuan dari kepuasan nasabah di Bank Mandiri dan mendapatkan kepuasan di Bank tersebut. Hal ini sejalan dalam penelitian yang dilakukan oleh Hairany dan Sangen (2014), Penelitian ini bermaksud mengetahui dan menganalisis pengaruh kepuasan dan kepercayaan terhadap loyalitas pelanggan.

2. Variabel Kepercayaan $\left(\mathrm{X}_{2}\right)$

Berdasarkan hasil uji regresi, terbukti bahwa variabel kepercayaan $\left(\mathrm{X}_{2}\right)$ memengaruhi loyalitas nasabah di Bank Mandiri Syariah Cabang Palu. Sedangkan dalam hasil uji t kepercayaan menjadi yang lebih dominan dengan hasil 0,000. Dimana dimensi yang dimasukkan dalam penelitian ini kemampuan (ability), dimana Bank Mandiri Syariah kompeten dalam kinerjanya dan mengetahui produk-produk yang mereka tawarkan. Dimensi yang kedua yaitu, kebaikan hati (benevolence), dimana Bank Mandiri dapat mengutamakan kepentingan nasabah dan rela membantu menyelesaikan masalah nasabah. Dimensi selanjutnya, integritas (integrity), dimana Bank Mandiri Syariah dapat menepati janji yang mereka buat serta kejujuran Bank Mandri tidak diragukan atas kejujuran kinerja mereka. Dimensi yang terakhir, yaitu kehormatan, dimana karyawan-karyawan Bank Mandiri Syariah berpenampilan yang sopan serta mampu memberikan kejelasan dalam layanan di sosial media. Oleh karena itu diharapkan Bank Mandiri Syariah dapat mempertahankan dan meingkatkan yang menjadi tujuan dari kepercayaan nasabah, karena kepercayaan nasabah berpengaruh positif terhadap loyalitas, sehingga membuat nasabah akan bertahan. Hal tersebut sejalan dengan penelitian yang dilakukan oleh Ningtyas dan Rachmad (2011), yang menyatakan bahwa kepercayaan berpengaruh positif dan signifikan terhadap loyalitas pelanggan. Penelitian lain yang juga sejalan dengan penelitian ini dilakukan oleh Ishak dan Luthfi (2011), yang menyatakan bahwa kepercayaan berpengaruh positif dan signifikan terhadap loyalitas pelanggan

\section{KESIMPULAN DAN SARAN}

\section{Kesimpulan}

Berdasarkan penelitian yang telah dijabarkan, maka diperoleh kesimpulan mengenai pengaruh kepuasan dan kepercayaan terhadap loyalitas nasabah di Bank Mandiri Syariah Cabang Palu yaitu:

1. Kepuasan dan kepercayaan secara simultan berpengaruh signifikan terhadap loyalitas nasabah di Bank Mandiri Syariah Cabang Palu.

2. Kepuasan berpengaruh signifikan terhadap loyalitas nasabah di Bank Mandiri Syariah Cabang Palu.

3. Kepercayaan berpengaruh signifikan terhadap loyalitas nasabah di Bank Mandiri Syariah Cabang Palu. 


\section{Saran}

Penelitian yang telah dilakukan memiliki beberapa saran yaitu:

1. Berdasarkan hasil jawaban kuesioner, mayoritas responden menjawab bahwa kepuasan dalam dimensi kualitas layanan yang mendapat nilai terendah. Maka disarankan kepada pihak-pihak Bank Mandiri agar meningkatkan kualitas layanan dalam menyediakan fasilitas tempat parkir yang memadai, agar kendaraan nasabah di Bank Mandiri akan tetap aman.

2. Berdasarkan hasil jawaban kuesioner, mayoritas responden menjawab bahwa kepercayaan dalam dimensi kehormatan yang menghasilkan nilai terendah dalam menjalnkankan bisnisnya, maka disarankan kepada pihak-pihak Bank Mandiri Syariah agar dapat meningkatkan kehormatan jujur dan jelas di media sosial instagram dari layanan yang ditawarkan.

3. Berdasarkan hasil jawaban kuesioner, mayoritas responden menjawab bahwa kepercayaan dalam dimensi kehormatan yang mendapat nilai rendah tersebut, maka disarankan kepada pihak-pihak Bank Mandiri Syariah agar dapat menjaga perusahan dalam menjalankan bisnisnya maka nasabah dapat mempertahankan loyalitas.

\section{REFERENSI}

Firdayanti, Restika. 2012. Persepsi Risiko Melakukan E-commerce dengan Kepercayaan Konsumen dalam Membeli Produk Fashion Online. Universitas Semarang.

Hasan Ali, (2014), Marketing dan Kasus-Kasus Pilihan, CAPS. Yogyakarta

Kasmir, (2012), Analisis Laporan Keuangan. Jakarta : pt.raja Grafindo Persada.

Lupiyoadi, Rambatdan A. Hamdani. 2011. Manajemen Pemaaran Jasa. Edisi Dua. Jakarta: Salemba Empat.

Salman Muhamammad. 2012. "Hubungan Makna antara Klausa dalam Kalimat Majemuk pada Terjemahan Surah Al Aufal. Skripsi. Surakarta: Universitas Muhammadiyah Surakarta.

Sugiyono, 2014 Metode Penelitian Usaha (Pendekatan, Kuantitatif, Kualitatif, dan R\&D), Bandung. Alfabeta.

Sugiyono, 2016, Desain Penelitian Manajemen, Bandung: Alfabeta

Sunyoto, 2013, Karakteristik pelanggan dan Pendekatai Pemasaran. Mitra Wacana Media: Jakarta.

Tjiptono, Fandi. 2010, Strategi Pemasaran, Edisi 2, Andi Offset, Yogyakarta. 